\title{
Hyphenated LC-ICP-MS/ESI-MS Identification of Halogenated Metabolites in South African Marine Ascidian Extracts
}

\author{
Candice L. Bromley ${ }^{a}$, Andrea Raab ${ }^{b}$, Shirley Parker-Nance ${ }^{c} \mathbb{D}^{\S}$, Denzil R. Beukes ${ }^{d} \mathbb{D}$, \\ Marcel Jaspars ${ }^{\mathrm{b}}$ and Michael T. Davies-Coleman ${ }^{\mathrm{e}, *}$ (iD \\ ${ }^{a}$ Department of Chemistry, Rhodes University, Grahamstown, 6140, South Africa. \\ ${ }^{b}$ Marine Biodiscovery Centre, Department of Chemistry, University of Aberdeen, Old Aberdeen, AB24 3UE, Scotland, U.K. \\ ${ }^{c}$ Department of Zoology, Nelson Mandela Metropolitan University, P.O. Box 77000, Port Elizabeth, 6031, South Africa. \\ ${ }^{d}$ School of Pharmacy, University of the Western Cape, Bellville, 7535, South Africa. \\ ${ }^{e}$ Department of Chemistry, University of the Western Cape, Bellville, 7535, South Africa.
}

Received 26 September 2017, revised 14 August 2018, accepted 19 August 2018.

\begin{abstract}
Extracts of 13 species of marine ascidian collected in Algoa Bay were analyzed by LC-ICP-MS/ESI-MS. This technique allows parallel analysis of the molecular species and the presence of certain elements. The LC-ICP-MS/ESI-MS technique was used to target iodinated metabolites in this study. Three ascidian species afforded the known 3,5-diiodo-4-methoxyphenethylamine (12), which was confirmed by the isolation of this metabolite from Aplidium monile. MS also suggested the presence of the known 3,5-dibromo-4-methoxyphenethylamine (10) and the new 3-bromo-5-iodo-4-methoxyphenethylamine (11) in the A. monile extract. The presence of the known 3,5-dibromotetramethyltyrosine (21) and the new 3-iodotetramethyltyrosine (23) in extracts of an unidentified Didemnum species was similarly proposed from MS evidence. This is the first report of the occurrence of iodinated metabolites in South African marine invertebrates.
\end{abstract}

KEYWORDS

Marine, ascidian, iodinated tyramine, iodinated tyrosine, LC-ICP-MS/ESI-MS.

\section{Introduction}

The sub-tidal rocky reefs along the western periphery of Algoa Bay, South Africa, provide a unique benthic habitat for a plethora of sessile filter feeders including diverse populations of endemic ascidians (also known as tunicates or sea squirts). The marine ascidians of Algoa Bay have recently been shown to be a source of halogenated secondary metabolites including the rubrolides (1-4) from Synoicum globosum ${ }^{1}$ and 3,6-dibromoindole (5), 6-bromo-3-chloroindole (6) and 6-bromo-2-oxindole (7) from Distaplia skoogi ${ }^{2}$ (Fig. 1).

As part of an ongoing search for new halogenated metabolites from the diverse ascidian populations of Algoa Bay, South Africa, we have expanded our search to target naturally occurring iodinated metabolites. Iodide and iodate ion concentrations in the ocean (c. $60 \mathrm{ppb})$ significantly exceed those in fresh water (c. 0.03-6 ppb). ${ }^{3,4}$ Of the 182 known iodinated secondary metabolites reported in a recent review of naturally occurring organoiodine compounds, more than $80 \%$ are marine. ${ }^{5}$ Given that over 5000 halogenated metabolites have been isolated from natural sources, organoiodines can be considered to be rare in nature. ${ }^{5}$ The first naturally occurring organoiodine to be identified, 'jodgorgosaure' (3,5-diiodotyrosine, 8 ), was originally isolated in 1896 from the marine octocoral (sea fan), Gorgonia cavolinii. ${ }^{6}$ 3,5-Diiodotyrosine and its mono-iodo analogue, 3-iodotyrosine (9), have also been reported from other eukaryotic marine phyla, e.g. kelp (order Laminariales). ${ }^{4}$ Kelp species can accumulate

* To whom correspondence should be addressed.E-mail: mdavies-coleman @uwc.ac.za iodide in concentrations 300000 times higher than the iodide concentration in the surrounding seawater, ${ }^{4}$ and as much as $10 \%$ of the iodine sequestered by kelp is incorporated into the organoiodines, 8 and $\mathbf{9} .{ }^{5}$ A possible endocrine hormone role for 8 and 9 has been postulated in which these two compounds may mediate cell to cell communication in algae and control developmental processes in other eukaryote species. ${ }^{5,7}$

Rapid identification of iodinated metabolites, and their brominated congeners, in Algoa Bay ascidian extracts was facilitated by access to the hyphenated LC-ICP-MS/ESI-MS facilities at the Marine Biodiscovery Centre at the University of Aberdeen. The University of Aberdeen hyphenated LC-ICP-MS/ESI-MS facility has successfully been used to, inter alia, explore the distribution of naturally occurring organoarsenic compounds, ${ }^{8-11}$ metal chelated ascidian metabolites, ${ }^{12-16}$ and recently identifying new secondary metabolites containing heteroatoms, e.g. iodinated metabolites in marine extracts. ${ }^{17}$ Hyphenated LC-ICP-MS/ESIMS, in which a high performance liquid inductively coupled plasma (ICP) and high resolution electrospray ionization (ESI) mass spectrometers arranged in parallel (Fig. 2), provides an opportunity to simultaneously acquire elemental and molecular information for the individual peaks separated by HPLC. High-resolution ESI-MS data then reveals possible molecular ions of the separated organic compounds from which molecular formulas can be predicted. In a marine bioprospecting context this technique can afford both the rapid de-replication of known compounds and the discovery of new secondary metabolites. 
<smiles>[R]Oc1ccc(/C=C2\OC(=O)C=C2c2ccc(O)c([R])c2)cc1[R]</smiles>

$1 \mathrm{R}^{1}=\mathrm{H}, \mathrm{R}^{2}=\mathrm{Br}, \mathrm{R}^{3}=\mathrm{Me}$

$2 \mathrm{R}^{1}=\mathrm{Br}, \mathrm{R}^{2}=\mathrm{H}, \mathrm{R}^{3}=\mathrm{H}$

$3 \mathrm{R}^{1}=\mathrm{Br}, \mathrm{R}^{2}=\mathrm{H}, \mathrm{R}^{3}=\mathrm{Me}$

$4 \mathrm{R}^{1}=\mathrm{Br}, \mathrm{R}^{2}=\mathrm{Br}, \mathrm{R}^{3}=\mathrm{H}$<smiles>[R]c1cc(CC(N)C(=O)O)cc(I)c1O</smiles>

$$
\begin{array}{ll}
8 & R=1 \\
9 & R=H
\end{array}
$$

$5 \mathrm{R}=\mathrm{Br}$

$6 \mathrm{R}=\mathrm{Cl}$<smiles>[R]c1c[nH]c2cc(Br)ccc12</smiles><smiles>[R]c1cc(CCN)cc([R])c1OC</smiles>

$10 \mathrm{R}^{1}=\mathrm{R}^{2}=\mathrm{Br}$

$11 \mathrm{R}^{1}=\mathrm{Br}, \mathrm{R}^{2}=$ ।

$12 R^{1}=R^{2}=$ ।

$17 \mathrm{R}^{1}=\mathrm{H}, \mathrm{R}^{2}=$ ।

$22 \mathrm{R}^{1}=\mathrm{H}, \mathrm{R}^{2}=\mathrm{Br}$<smiles>COc1c(I)cc(CCNC(=O)NCCc2cc(I)c(OC)c(I)c2)cc1I</smiles><smiles>COc1c(I)cc(CC[NH3+])cc1I</smiles><smiles>COc1c(I)cc(CC(N)=O)cc1I</smiles>

15<smiles>COc1c(I)cc(CCNC=O)cc1I</smiles>

16<smiles>COc1c(I)cc(CCNC(=O)C(=O)NCCc2cc(I)c(OC)c(I)c2)cc1I</smiles>

18<smiles>CN(C)CCCOc1c(I)cc(CCN(C)C)cc1I</smiles>

20

Figure 1 Selected metabolites from marine invertebrates and algae

\section{Materials and Methods}

\subsection{General}

LC-ICP-MS/ESI-MS analyses were carried out using an Agilent 1100 series HPLC with ESI-MS performed on a Thermo Orbitrap mass spectrometer whilst ICP-MS was performed on an Agilent 8800 triple quad ICP-MS, with micro-flow PFA nebulizer and Pt cones, and $7 \% \mathrm{O}_{2}$ reaction gas. Chromatography for LC-ICPMS/ESI-MS analyses were carried out by injecting $100 \mu \mathrm{L}$ of sample onto an analytical C18 Waters SunFire column with a solvent flow rate of $1 \mathrm{~mL} \mathrm{~min}^{-1}$ and gradient profile of $100 \% \mathrm{H}_{2} \mathrm{O}$<smiles>COc1c(I)cc(CCNC(=O)c2ccccc2)cc1I</smiles>

19<smiles>[R]c1cc(CC(C(=O)O)[N+](C)(C)C)cc([R])c1OC</smiles>

$21 \mathrm{R}^{1}=\mathrm{R}^{2}=\mathrm{Br}$

$23 \mathrm{R}^{1}=\mathrm{I}, \mathrm{R}^{2}=\mathrm{H}$ 


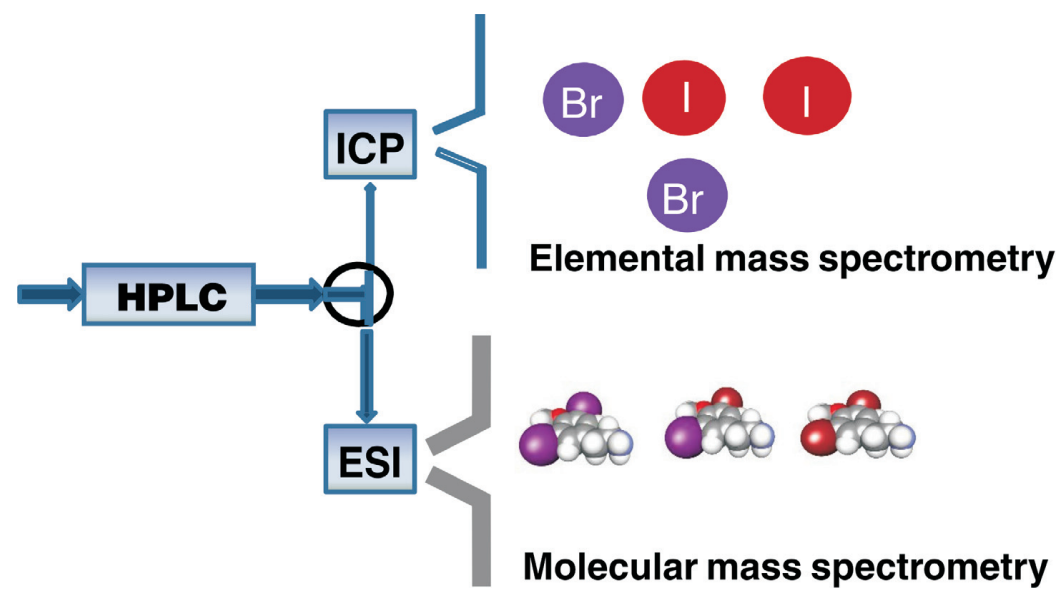

Figure 2 Schematic diagram of the hyphenated LC-ICP-MS/ESI-MS technique. Circa $85 \%$ of the HPLC eluent is diverted to the ESIMS and the remainder to the ICPMS.

reported directly from the NMR spectra. Mass spectrometry of purified compound $\mathbf{1 2}$ was performed on a Waters API Q-TOF Ultima instrument using electrospray ionization in the positive ion mode (ESI+) at the University of Stellenbosch Central Analytical Facility.

\subsection{Collection of Ascidian Material}

The ascidian Aplidium monile Monniot, F., $2001^{18}$ Aplousobranchia: Polyclinidae was collected by SCUBA from a depth of $12-15 \mathrm{~m}$ at Bell Buoy Reef, Algoa Bay, South Africa (33.9833ㅇ, $25.6987^{\circ} \mathrm{E}$ ), on 18 November 2011 and given the voucher code TIC2011-032. Polycitor sp. (suborder Aplousobranchia, family Polycitoridae) was collected by SCUBA at a depth of $21 \mathrm{~m}$ from Haarlem Reef, Algoa Bay, South Africa (33.9889 $\left.\mathrm{S}, 25.6984^{\circ} \mathrm{E}\right)$, on 23 July 2004 and given the voucher code SAF2004-068. Leptoclinides sp. was collected by SCUBA from the White Sands Reef, Algoa Bay, South Africa, $\left(33.9961^{\circ} \mathrm{S}, 25.7072^{\circ} \mathrm{E}\right)$, from a depth of $21 \mathrm{~m}$, on 13 July 2004 and given the sample code SAF2004-015. Didemnum sp.2 (suborder Aplusobranchia, family Didemnidae) was collected by SCUBA at a depth of $18 \mathrm{~m}$ at White Sands Reef, Algoa Bay, South Africa (33.9986 ${ }^{\circ}$, $\left.25.7096^{\circ} \mathrm{E}\right)$, on 20 July 2004 and given the sample code SAF2004-61. After collection in the field all ascidian samples were carefully separated, cleaned of epibionts and frozen immediately as whole specimens of individual species and kept at $-20{ }^{\circ} \mathrm{C}$ until extracted.

\subsection{Extraction of Frozen Ascidian Samples for LC-ICP-MS/ESI-MS Analysis}

All glassware and laboratory equipment used in the preparation of extracts for LC-ICP-MS/ESI-MS screening were acid washed using $10 \% \mathrm{HNO}_{3}$ and subsequently rinsed using MilliPore ${ }^{\circledR}$ water. HPLC grade solvents were used and to prevent contamination. Extracts of internal portions of each species of ascidian ( $\sim 15$ g wet mass) were made using HPLC grade $\mathrm{MeOH}$ and $\mathrm{CH}_{2} \mathrm{Cl}_{2}$. Extractions were carried out in the normal way except that all glassware and tools used were acid washed and an iced water bath was used when sonicating the material. The crude ascidian extracts were stored at $-20^{\circ} \mathrm{C}$ until LC-ICPMS/ESI-MS screening. Aliquots of methanol solutions of the crude organic extracts were used for the LC-ICP-MS/ESI-MS speciation studies.

\subsection{Isolation and Characterization of $\mathbf{1 2}$}

The crude A. monlie extract (23.90 g) from the LC-ICP-MS/ ESI-MS screen was partitioned between dichloromethane and aqueous methanol (70 \% aq. methanol). The $\mathrm{MeOH}$ partition $(676.0 \mathrm{mg})$ was fractionated using a C-18 Sep-Pak ${ }^{\circledast}$ cartridge (Waters, $10 \mathrm{~g}$ ). Seven fractions were collected based on the polarity of the solvents used to flush the cartridge (water, $10 \% \mathrm{MeCN}_{\mathrm{aq}}, 20 \% \mathrm{MeCN}_{\mathrm{aq}}, 40 \% \mathrm{MeCN}_{\mathrm{aq}}, 60 \% \mathrm{MeCN}_{\mathrm{aq}}, 80 \%$ $\mathrm{MeCN}_{\mathrm{aq}}$ and $100 \% \mathrm{MeCN}$ ). The fourth fraction yielded $5.0 \mathrm{mg}$ of 12.

3,5-Diido-4-methoxyphenethylamine (12): White amorphous solid; ${ }^{1} \mathrm{H}$ and ${ }^{13} \mathrm{C}$ NMR data were consistent with published data, ${ }^{19,20}$ HRESIMS $m / z 403.9000$ (calcd for $\mathrm{C}_{9} \mathrm{H}_{11} \mathrm{NOI}_{2}\left[(\mathrm{M}+\mathrm{H})^{+}\right]$, $403.9003 \Delta 0.3 \mathrm{mmu}$ ).

\section{Results and Discussion}

Representative specimens of 13 ascidian species from five different families (Clavelinidae, Didemnidae, Holozoidae, Polyclinidae and Polycitoridae), belonging to the suborder Aplousobranchia, were collected by SCUBA from Algoa Bay over the period 2004-2011, carefully separated from any epibionts and frozen separately as whole specimens of individual species $\left(-20^{\circ} \mathrm{C}\right)$ immediately after collection. Portions of the frozen material were carefully extracted with methanol and dichloromethane for LC-ICP-MS/ESI-MS analysis following an established protocol ${ }^{16}$ that minimized the possibility of metal ion cross-contamination. The mass spectrometry data revealed that four of the ascidian extracts: Aplidium monile, Polycitor sp., Leptoclinides sp., and Didemnum sp. 2 (Fig. 3) contained both iodinated and brominated metabolites. Iodinated metabolites have not previously been reported from South African marine invertebrates.

The ICP-MS extracted ion chromatograms (EIC), selected for the ${ }^{127} \mathrm{I}$ and ${ }^{79} \mathrm{Br}$ isotopes, together with the matching HRESI EICs and the corresponding mass spectra for the methanolic extract from A. monile are presented in Fig. 4. The isotopic ratios of the pseudo molecular ion $(\mathrm{M}+\mathrm{H})$ peaks in the ESI mass spectra of $\mathbf{1 0}$ (1:2:1) and 11 (1:1) suggested di- and monobromination in these two compounds, respectively. Mass fragmentation, consistent with the loss of ${ }^{127} \mathrm{I}$, in the mass spectra of $\mathbf{1 1}$ and $\mathbf{1 2}$ corroborated the presence of iodine in these compounds. The loss of 17 atomic mass units $\left(\mathrm{M}+\mathrm{H}-\mathrm{NH}_{3}\right)$ from the pseudomolecular ions in the ESI mass spectra of 10-12 indicated the probable presence of a common amino functionality in these compounds.

The molecular formulas of $10\left(\mathrm{C}_{9} \mathrm{H}_{12} \mathrm{ONBr}_{2}, \mathrm{M}+\mathrm{H} 309.9260\right.$ $\Delta \mathrm{mmu} 0.2), \mathbf{1 1}\left(\mathrm{C}_{9} \mathrm{H}_{12} \mathrm{ONBrI}, \mathrm{M}+\mathrm{H} 355.9141 \Delta \mathrm{mmu}-0.3\right)$, and 12 $\left(\mathrm{C}_{9} \mathrm{H}_{12} \mathrm{ONI}_{2}, \mathrm{M}+\mathrm{H} 403.90030 \Delta \mathrm{mmu}-0.3\right)$, suggested from the HRMS data, were key for the rapid dereplication of the 3,5-dibromo-4-methoxyphenethylamine and 3,5-diiodo-4-methoxy- 

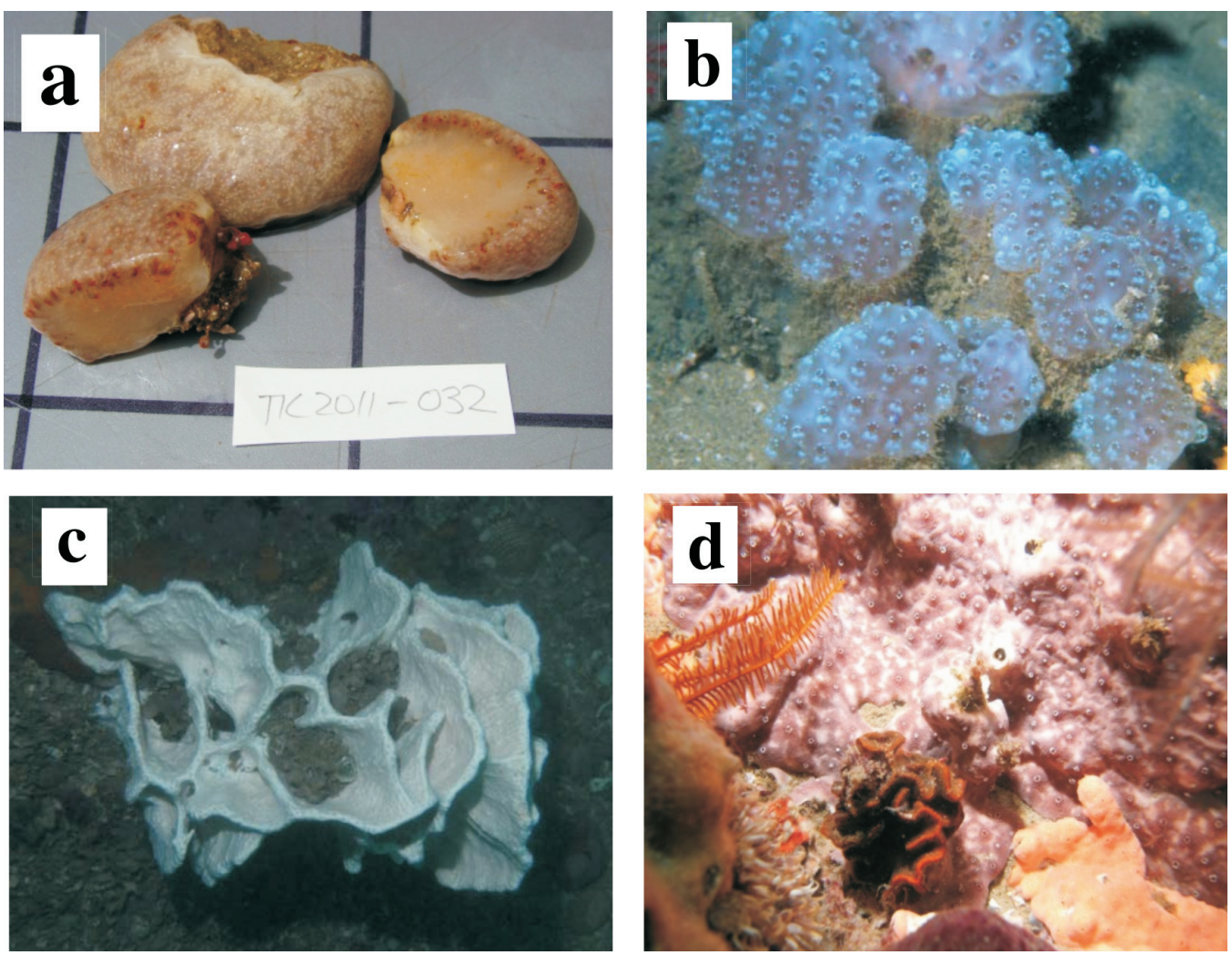

Figure 3 Surface (a) and underwater (b-d) photographs of (a) Aplidium monile, (b) Polycitor sp., (c) Leptoclinides sp. and (d) Didemnum sp. 2 from Algoa Bay, South Africa. (Photographs S. Parker-Nance.)

phenethylamine structures of $\mathbf{1 0}$ and $\mathbf{1 2}$ respectively. ${ }^{21,22}$ No compounds with the molecular formula $\mathrm{C}_{9} \mathrm{H}_{12} \mathrm{ONBrI}$ were identified in the literature suggesting that the proposed 3-bromo, 5-iodo-4-methoxyphenethylamine structure proposed for $\mathbf{1 1}$ was unprecedented.

Partitioning of the A. monile extract between $70 \%$ aqueous methanol and dichloromethane, followed by further fractionation of the methanol partition fraction on a C18 SepPak ${ }^{\circledR}$ cartridge afforded $\mathbf{1 2}$ as the only metabolite in the $40 \%$ aqueous acetonitrile fraction. The ${ }^{1} \mathrm{H}$ and ${ }^{13} \mathrm{C}$ NMR data of $\mathbf{1 2}$ were consistent with published data for this compound. Further exhaustive semi-preparative HPLC of the C18 SepPak ${ }^{\circledR}$ fractions failed to yield either 10 or 11 suggesting that these two compounds may be present in trace amounts in the ascidian. The detection of very low concentrations of $\mathbf{1 0}$ and $\mathbf{1 1}$ in the presence of the major metabolite $\mathbf{1 2}$ further highlights the sensitivity and value of the LC-ICP-MS/ESI-MS technique.

Three decades ago Ireland and Sesin reported the isolation of $\mathbf{1 2}$ together with its urea derivative $\mathbf{1 3}$ from an unidentified species of Didemnum ascidian. ${ }^{19}$ This was the first isolation of these two compounds from a natural source. Compound $\mathbf{1 1}$ was later isolated as the major compound in two ascidians, an Indonesian Didemnum sp. and Palauan specimens of D. rubeum. ${ }^{23,24}$ More recently the chemistry of D. rubeum was revisited and an expanded series of iodinated tyramine derivatives were isolated from this ascidian that included $\mathbf{1 2}$ and $\mathbf{1 3}$ and six new analogues 14-19. ${ }^{20}$ While we report here the first isolation of $\mathbf{1 2}$ from an African ascidian, an Axinella sponge collected off the coast of Ghana recently afforded the related iodotyramine analogue dakaramine (20). ${ }^{17}$

Compound $\mathbf{1 0}$ appears to be less common, in the marine environment, than its iodo congener. The only previously reported isolation of $\mathbf{1 0}$ was by Ireland and co-workers ${ }^{25}$ from the Indonesian ascidian Eudistoma sp.. However, related analogues of 10, e.g. the tetramethylated tyrosine analogue $\mathbf{2 1}$ and the monobromo-tyramine $\mathbf{2 2}$ have been isolated from the sponge Verongula sp. and the ascidian Cnemidocarpa bicornuta, respectively. ${ }^{25-27}$ In a biological evaluation of a series of synthetic bromotyramines Schoenfeld et al. found $\mathbf{1 0}$ exibited potent antifouling and cytotoxic properties. ${ }^{28}$

The C3 monohalogenation and C3, C5 dihalogenation of the phenyl ring in halogenated marine tyramine and tyrosine analogues appears ubiquitous, and without exception (Fig. 1), thus suggesting that other possible regioisomers within this cohort of halogenated natural products are unlikely. Biosynthetic arguments were therefore used to support the C3, C5 dihalogenation pattern proposed for $\mathbf{1 0}$ and 11. Interestingly, albeit speculative from high-resolution mass data alone, this is the first report of an asicidian yielding $\mathbf{1 0}$ and $\mathbf{1 2}$ and the previously unreported 11. Similar hyphenated LC-ICP-MS/ESI-MS examination of the extracts of the Polycitor sp. and Leptoclinides sp. (Fig. $3 \mathrm{~b}, \mathrm{c}$ ) also revealed the presence of $\mathbf{1 2}$ in these extracts suggesting that this metabolite is relatively common in Algoa Bay ascidian species with $25 \%$ of the small cohort of 13 ascidians screened in this study containing this compound. Although the LC-ICP-MS/ESI-MS mass data suggested the presence of further iodinated and brominated metabolites in both the Polycitor and Leptoclinides extracts, the structures of these compounds could not be resolved from the mass data. The paucity of ascidian material in hand prevented their isolation and identification by other spectroscopic techniques.

The ICP-MS EICs, selected for the ${ }^{127} I$ and ${ }^{79} \mathrm{Br}$ isotopes, together with the matching HRESI EICs and the corresponding mass spectra of selected peaks from LC-ICP-MS/ESI-MS of the methanolic extract from Didemnum sp 2 are presented in Fig. 5. The 1:2:1 isotopic ratio of the molecular ion $\left(\mathrm{M}^{+}\right)$peak in the ESI mass spectrum of the compound with TR $10.6 \mathrm{~min}(\mathrm{~m} / \mathrm{z} 393.9650$; 395.9629 ; 397.9607) was indicative of dibromination in this 


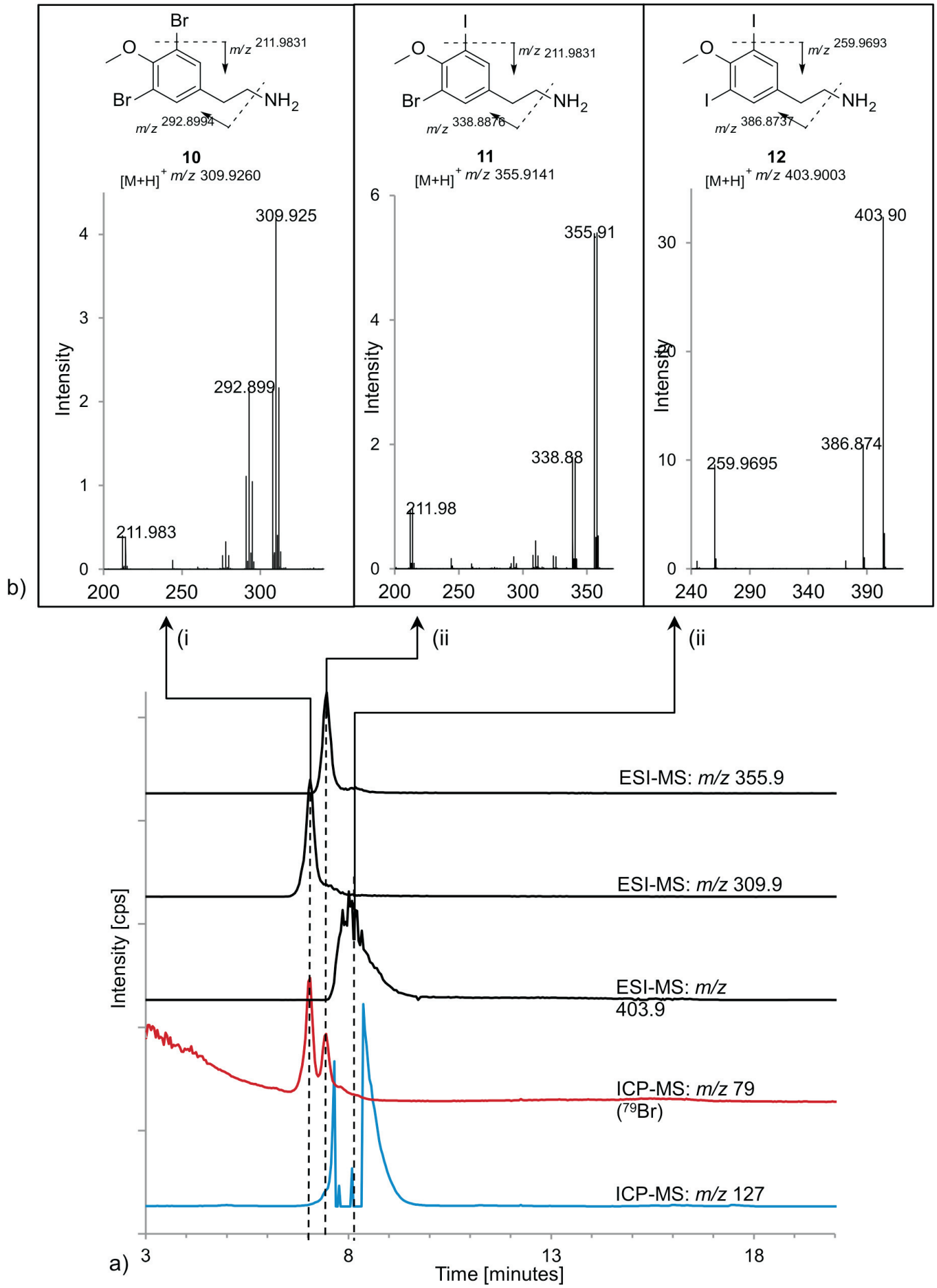

Figure 4 Halogenated tyramine analogues detected in the A. monile extract by LC-ICP-MS/ESI-MS. (a) Selected ICP-MS $\left({ }^{127} \mathrm{I}-\mathrm{blue}\right.$ trace; ${ }^{79} \mathrm{Br}-$ red trace) and ESI-MS extracted ion chromatograms; (b) ESI mass spectra and proposed structures of 10, $\mathrm{T}_{\mathrm{R}} 7.06 \mathrm{~min} ; 11, \mathrm{~T}_{\mathrm{R}} 7.46 \mathrm{~min} ; \mathrm{and} \mathbf{1 2}, \mathrm{T}_{\mathrm{R}} 8.09 \mathrm{~min}$.

compound. The closest fit molecular formula simulation ${ }^{29}$ for a molecular mass of $m / z 395.9629$ suggested a molecular formula of $\mathrm{C}_{13} \mathrm{H}_{18} \mathrm{O}_{3} \mathrm{NBr}_{2}(\Delta \mathrm{mmu} 0.2)$. A literature search ${ }^{21}$ revealed only one compound from a marine source, 3,5-dibromotetramethyltyrosine (21) with this molecular formula and comparable molecular mass. Compound $\mathbf{2 1}$ was isolated by Ciminiello et al. from the Caribbean Verongida sponge Aiolochroia crassa (synonymous with Pseudoceratina crassa) ${ }^{26}$ and was found to be inactive in both anti-fouling and anti-parasitic bioassays. ${ }^{30,31}$

The iodine $\left({ }^{127} \mathrm{I}\right)$ ICP-MS EIC (Fig. 5a) revealed two major peaks
(TR 8.64 and $13.99 \mathrm{~min}$ ). Unfortunately, no ESI mass spectrum was observed at $T_{R} 13.99 \mathrm{~min}$ and the source of this peak in the ${ }^{127} \mathrm{I}$ EIC is unknown. A molecular formula of $\mathrm{C}_{13} \mathrm{H}_{19} \mathrm{O}_{3} \mathrm{NI}\left(\mathrm{M}^{+}\right.$ $\mathrm{m} / \mathrm{z} 364.041 \Delta \mathrm{mmu}-0.3$ ) emerged for 23 from the closest fit molecular formula simulation. ${ }^{29}$ With the putative structure of $\mathbf{2 1}$ in hand the 3-iodotetramethyltyrosine structure for $\mathbf{2 3}$ was proposed. Further mass spectroscopic evidence in support of the chemical structure of $\mathbf{2 3}$ (Fig. 5b) emerged from the fragment ion $\left(\mathrm{m} / \mathrm{z} 237.0949, \mathrm{M}^{+}{ }^{127} \mathrm{I}\right)$ in the HRESI mass spectrum and the product ions from tandem mass spectrometry (MSMS) of the 


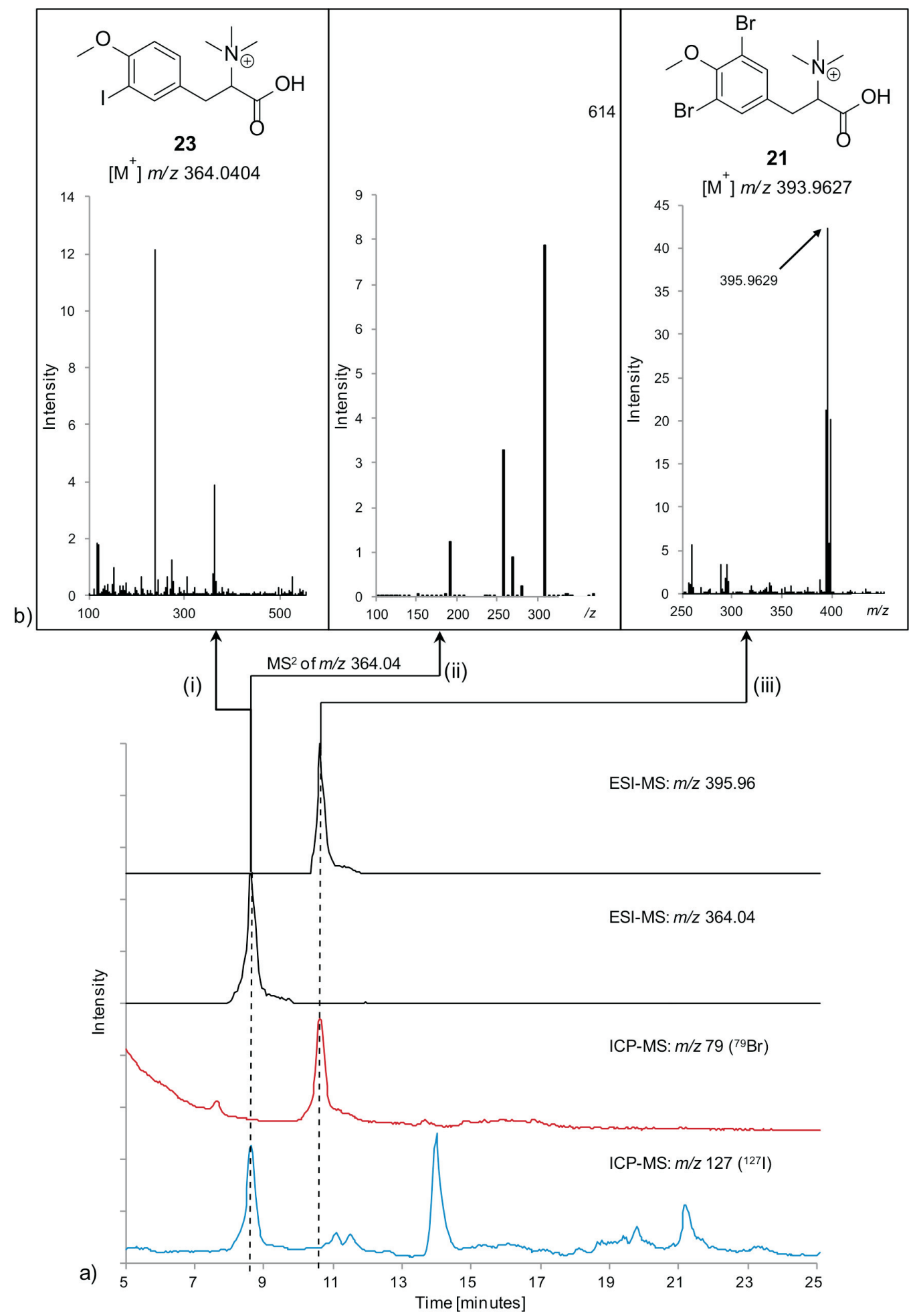

Figure 5 Halogenated tetramethylated tyrosine analogues detected in the LC-ICP-MS/ESI-MS spectra of the extract of Didemnum sp.2 (a) Selected ICP-MS ( ${ }^{1271}$ - blue trace; ${ }^{79} \mathrm{Br}$ - red trace) and ESI-MS extracted ion chromatograms; (b) HRESI mass spectra and proposed structures of $23, \mathrm{~T}_{\mathrm{R}} 8.6$ min; 21, $\mathrm{T}_{\mathrm{R}} 10.6 \mathrm{~min}$; and $\mathrm{HRMS}^{2}$ spectrum of $\mathrm{M}^{+}$peak $(\mathrm{m} / \mathrm{z} 364.04)$ of 23.

$\mathrm{M}^{+}$precursor ion $\left(\mathrm{m} / \mathrm{z} 304.9661, \mathrm{M}^{+}-\mathrm{N}\left(\mathrm{CH}_{3}\right)_{3} ; \mathrm{m} / \mathrm{z} 258.9614\right.$, $\mathrm{M}^{+}-\mathrm{HCOOH}-\mathrm{N}\left(\mathrm{CH}_{3}\right)_{3} ; \mathrm{m} / z$ 178.0624, $\left.\mathrm{M}^{+}-\mathrm{I}-\mathrm{N}\left(\mathrm{CH}_{3}\right)_{3}\right)$. A search of the chemical literature ${ }^{21,22}$ revealed that 23 has not been previously reported from nature. Regrettably, the paucity of Didemnum sp. 2 available precluded the chromatographic isolation of $\mathbf{2 1}$ and $\mathbf{2 3}$ for further spectroscopic analysis.

\section{Conclusion}

This preliminary survey of the distribution of halogenated metabolites in a small subset of the ascidian fauna in Algoa Bay South Africa suggests that iodinated and brominated tyrosines and tyramines may be relatively common in aplousobranch ascidians. The potential of the LC-ICP-MS/ESI-MS technique to detect these metabolites in trace amounts is clearly apparent.

\section{Acknowledgements}

The authors would like to thank Professor Bill Fenical of the Scripps Institution of Oceanography, San Diego, U.S.A., for the 
generous donation of funding which enabled the first large-scale SCUBA collection of marine ascidians in Algoa Bay, South Africa, in 2004. C.B., M.D.C. and M.J. acknowledge the support of a Royal Society international collaborative grant which enabled travel between universities in South Africa and the U.K. Financial support from Rhodes University and the South African National Research Foundation through the SeaChange Programme is gratefully acknowledged.

\section{${ }^{8}$ ORCID iDs}

\section{S. Parker-Nance:}

D.R. Beukes:

\section{M.T. Davies-Coleman:}$$
\text { (iD) }
$$

orcid.org/0000-0003-4231-6313 orcid.org/0000-0002-5684-6094 orcid.org/0000-0001-5344-894X

\section{References and Notes}

1 J. Sikorska, S. Parker-Nance, M.T. Davies-Coleman, O.B. Vining, A.E. Sikora and K.L. McPhail, Antimicrobial Rubrolides from a South African species of Synoicum tunicate, J. Nat. Prod., 2012, 75, 1824-1827.

2 C.L. Bromley, S. Parker-Nance, J.-A. de la Mare, A.L. Edkins, D.R. Beukes and M.T. Davies-Coleman, Halogenated oxindole and indoles from the South African marine ascidian Distaplia skoogi, S. Afr. J. Chem., 2013, 66, 64-68.

3 V.M. Dembitsky, Biogenic iodine and iodine containing metabolites, Nat. Prod. Commun., 2006, 1, 139-175.

4 S. Venturi, Evolutionary significance of iodine, Curr. Chem. Biol., 2011, 5, 155-162.

5 L. Wang, X. Zhou, M. Fredimoses, S. Liao and Y. Liu. Naturally occurring organoiodines, RSC Adv., 2014, 4, 57350-57376.

6 E. Drechsel, Chemistry of some marine animals, Z. Biol., 1896, 33, 85-107.

7 S.J. Crockford, Evolutionary roots of iodine and thyroid hormones in cell-cell signaling, Integr. Comp. Biol., 2009, 49, 155-166.

8 A. Raab, S.H. Wright, M. Jaspars, A.A. Meharg and J. Feldmann, Pentavalent arsenic can bind to biomolecules, Angew. Chem. Int. Ed. Engl., 2007, 46, 2594-2597.

9 D.S. Urgast, G.C. Adams, A. Raab and J. Feldmann, Arsenic concentration and speciation of the marine hyperaccumulator whelk Buccinum undatum collected in coastal waters of northern Britain, J. Environ. Monit., 2010, 12, 1126.

10 K.O. Amayo, A. Petursdottir, C. Newcombe, H. Gunnlaugsdottir, A. Raab, E.M. Krupp and J. Feldmann, Identification and quantification of arsenolipids using reversed-phase HPLC coupled simultaneously to high-resolution ICPMS and high-resolution electrospray MS without species-specific standards, Anal. Chem., 2011, 83, 3589-3595.

11 A. Raab, C. Newcombe, D. Pitton, R. Ebel and J. Feldmann, Comprehensive analysis of lipophilic arsenic species in a brown alga (Saccharina latissima)., Anal. Chem., 2013, 85, 2817-2824.

12 L.A. Morris, J. Jantina, K. Van Den Bosch, K. Versluis, S. Thompson and M. Jaspars, Structure determination and $\mathrm{MS}^{\mathrm{n}}$ analysis of two new Lissoclinamides isolated from the Indo Pacific ascidian Lissoclinum patella: NOE restrained molecular dynamics confirms the absolute stereochemistry derived by degradative methods, Tetrahedron, 2000, 56, 8345-8353.

13 L.A. Morris, M. Jaspars, J.J. Kettenes-Van Den Bosch, K. Versluis,
A.J.R. Heck, S.M. Kelly and N.C. Price, Metal binding of Lissoclinum patella metabolites. Part 1: Patellamides A, C and ulithiacyclamide A, Tetrahedron, 2001, 57, 3185-3197.

14 L.A. Morris, B.F. Milne, M. Jaspars, J.J. Kettenes-van den Bosch, K. Versluis, A.J. R. Heck, M. Kelly and N.C. Price, Metal binding of Lissoclinum patella metabolites. Part 2: Lissoclinamides 9 and 10, Tetrahedron, 2001, 57, 3199-3207.

15 P. Comba, N. Dovalil, L.R. Gahan, G.R. Hanson and M. Westphal, Cyclic peptide marine metabolites and CuII, Dalton Trans., 2014, 43, 1935-1956.

16 S.H. Wright, A. Raab, J.N. Tabudravu, J. Feldmann, P.F. Long, C.N. Battershill, W.C. Dunlap, B.F. Milne and M. Jaspars, Marine metabolites and metal ion chelation: intact recovery and identification of an iron(II) complex in the extract of the ascidian Eudistoma gilboviride, Angew. Chem. Int. Ed. Engl., 2008, 47, 8090-8092.

17 K. Kyeremeh, K.S. Acquah, R. Appiah-Opong, M. Jaspars and H. Deng, Effective detection, isolation and characterization of dakaramine from Ghanaian Axinella sp and bioactivity, J. Chem. Appl., 2014, 1, 1-4, DOI: 10.13188/ 2380-5021.1000003

18 C. Monniot, F. Monniot, C.L. Griffiths and M. Schleyer, South African ascidians, Ann. S. Afr. Mus., 2001, 108, 1-1417.

19 T.F. Sesin and C.M. Ireland, Iodinated phenethylamine products from a didemnid tunicate, Tetrahedron Lett., 1984, 25, 403-404.

20 G. Solano, C.A. Motti and M. Jaspars, New iodotyramine derivatives from Didemnum rubeum, Tetrahedron, 2009, 65, 7482-7486.

21 MarinLit http://pubs.rsc.org/marinlit/

22 Scifinder Scholar http://www.cas.org/products/scifinder

23 C.J. Smith, D.A. Venables, C. Hopmann, C.E. Salomon, J. Jompa, A. Tahir, D.J. Faulkner and C.M. Ireland, Plakinidine D, a new pyrroloacridine alkaloid from two ascidians of the genus Didemnum, J. Nat. Prod., 1997, 60, 1048-1050.

24 P.W. Ford and B.S. Davidson, Plakinidine D, a new pyrroloacridine alkaloid from the ascidian Didemnum rubeum, J. Nat. Prod., 1997, 60, 1051-1053.

25 R.M. Van Wagoner, J. Jompa, A. Tahir and C.M. Ireland, Trypargine alkaloids from a previously undescribed Eudistoma sp. ascidian, J. Nat. Prod., 1999, 62, 794-797.

26 P. Ciminiello, E. Faitorusso and S. Magno, Chemistry of Verongida sponges, III. Constituents of a Caribbean Verongula sp., J. Nat. Prod., 1994, 57, 1564-1569.

27 B.S. Lindsay, C.N. Battershill and B.R. Copp, Isolation of 2-(3'-bromo4'-hydroxyphenol) ethanamine from the New Zealand ascidian Cnemidocarpa bicornuta, J. Nat. Prod., 1998, 61, 857-858.

28 R.C. Schoenfeld, S. Conova, D. Rittschof and B. Ganem, Cytotoxic, antifouling bromotyramines: a synthetic study on simple marine natural products and their analogues, Bioorg. Med. Chem., 2002, 12, $823-825$.

29 Copyright Thermo Fisher Scientific Inc.

30 J.A. Diers, H.K. Pennaka, J. Peng, J.J. Bowling, S.O. Duke and M.T. Hamann, Structural activity relationship studies of zebra mussel antifouling and antimicrobial agents from Verongid sponges, J. Nat. Prod., 2004, 3, 2117-2120.

31 E. Galeano, A. Martinez, O. Thomas, S. Robledo and D. Munoz, Antiparasitic bromotyrosine derivative from the Caribbean marine sponge Aiolochroia crassa, Quim, Nov., 2012, 35, 1189-1193. 